\title{
BMJ Global Health Climate change and seasonal floods: potential long-term nutritional consequences for children in Kerala, India
}

\author{
Raya Muttarak, ${ }^{\circledR 1,2}$ Anna Dimitrova ${ }^{2}$
}

\begin{abstract}
To cite: Muttarak R, Dimitrova A Climate change and seasonal floods: potential long-term nutritional consequences for children in Kerala, India. BMJ Glob Health 2019;4:e001215. doi:10.1136/ bmjgh-2018-001215
\end{abstract}

Handling editor Peter MacGarr Rabinowitz

- Additional material is published online only. To view please visit the journal online (http://dx.doi.org/10.1136/ bmjgh-2018-001215).

Received 10 0ctober 2018 Revised 27 February 2019 Accepted 1 March 2019

Check for updates

(c) Author(s) (or their employer(s)) 2019. Re-use permitted under CC BY-NC. No commercial re-use. See rights and permissions. Published by BMJ.

${ }^{1}$ School of International Development, University of East Anglia, Norwich, UK

${ }^{2}$ World Population Program, International Institute for Applied Systems Analysis, Laxenburg, Austria

Correspondence to Ms Anna Dimitrova anna.dimitrova@wu.ac.at

\section{CLIMATE CHANGE AND SEASONAL FLOODS}

The latest report on the impacts of global warming of $1.5^{\circ} \mathrm{C}$ from the Intergovernmental Panel on Climate Change has warned that without substantial cuts in carbon dioxide emissions, the world will reach the threshold of $1.5^{\circ} \mathrm{C}$ warmer than preindustrial levels as early as in 2030 . With $1.5^{\circ} \mathrm{C}$ warmer, some regions including South and Southeast Asia and Central Africa will experience an increase in flood hazard due to high flows. ${ }^{1}$ The increasing flood risks are alarming, especially their impacts on vulnerable populations with low coping and adaptive capacities. In particular, floods can have long-run impacts on health which in turn deteriorate human capital, a key driver of sustainable development. Using the example of the recent floods in Kerala, India, we discuss the potential impacts of floods on childhood development and present immediate measures to reverse the potential damage.

During the monsoon season this year, India has experienced a particularly high amount of rainfall. The data from India Meteorological Department show that from 1 June to 20 August 2018, the amount of rainfall in Kerala increased by $40 \%$ compared with the normal trend. ${ }^{2}$ The heavy rainfall on 8 August 2018 pressured Indian states in the south to open many dams due to the fear of water overflow. The discharge of excess water from the water reservoirs across Kerala state and its neighbouring states resulted in the worst flood in Kerala since 1924. As a result of prolonged heavy downpour and a series of unprecedented floods, it is estimated that over 483 people lost their lives ${ }^{3}$ and over 1.4 million being displaced from their homes. ${ }^{4}$

Apart from fatality of human lives, the severe floods also destroyed and damaged roads, homes, schools and hospitals and

\section{Summary box}

In the aftermath of the worst flooding Kerala has experienced in nearly a century, we highlight the urgency of considering the long-term health consequences of floods, especially on young children.

- Based on the recent Demographic and Health Survey data for India in 2015-2016, we provided evidence showing that abnormally wet conditions increased the likelihood of undernutrition for children aged under 5 as measured by stunting and wasting.

- Experiencing floods during infancy, being a girs with illiterate mothers making a child particularly vulnerable to being stunted while living in the rural area increases the risk of being wasted due to floods.

- We put forward that nutritional and water and sanitation interventions at the critical period of flood exposure can reverse the course of undernutrition which in turn can reduce the cost of poor human development in the long run.

basic sanitation systems. In the aftermath of Kerala floods, there have already been reported cases of leptospirosis, dengue fever, malaria and acute diarrheal disease. Indeed, mortality, injuries and communicable diseases including waterborne diseases and vectorborne diseases are the common shortterm health risks found in the literature after floods. ${ }^{5}$ On the other hand, the evidence on long-term health effects of floods, especially on children, is rather limited. Recent systematic reviews of the literature however reported some evidence of elevated risks of non-communicable diseases, psychological health, malnutrition and poor birth outcomes after flood exposure. ${ }^{67}$

\section{POTENTIAL IMPACTS ON CHILDREN IN KERALA}

In particular, the potential long-run impacts of floods on children is worrying. Disruptions in food supply and contaminated water 
leading to diarrheal illness make children under 5 years of age the most susceptible to undernutrition. With almost three quarters of its population relying on agriculture for their livelihood, floods can destroy crop and livestock production threatening India's household food security. Likewise, floods increase the risk of household falling into poverty, especially for those relying on natural resources for their livelihood. ${ }^{8}$ As a consequence, household may have to reduce the quantity of food intake in order to cope with their income reduction, a common strategy employed during climatic shocks in India. ${ }^{9} 10$ Exposure to floods thus is likely to increase the risk of child malnutrition. Even in a period without any calamities, childhood undernutrition in India is among the highest in the world with $38.3 \%$ of boys and $37.4 \%$ of girls aged under 5 in 2015 had stunted growth. ${ }^{11}$ If floods do exacerbate malnutrition, then public intervention is urgently needed.

There is however no scientific consensus whether flood exposure does lead to malnutrition due to limited number of empirical studies. ${ }^{12}$ Current evidence on the association between floods and malnutrition seems to be context-specific. ${ }^{13} 14$ In order to provide some scientific insight into the potential deteriorating impacts of floods on child health in Kerala, we exploit the Demographic and Health Survey data for India collected in 2015-2016 and climate data from the Climatic Research Unit at the University of East Anglia. The Standardized Precipitation and Evapotranspiration Index (SPEI), which combines information on precipitation and potential evapotranspiration due to temperature, is used to identify flood

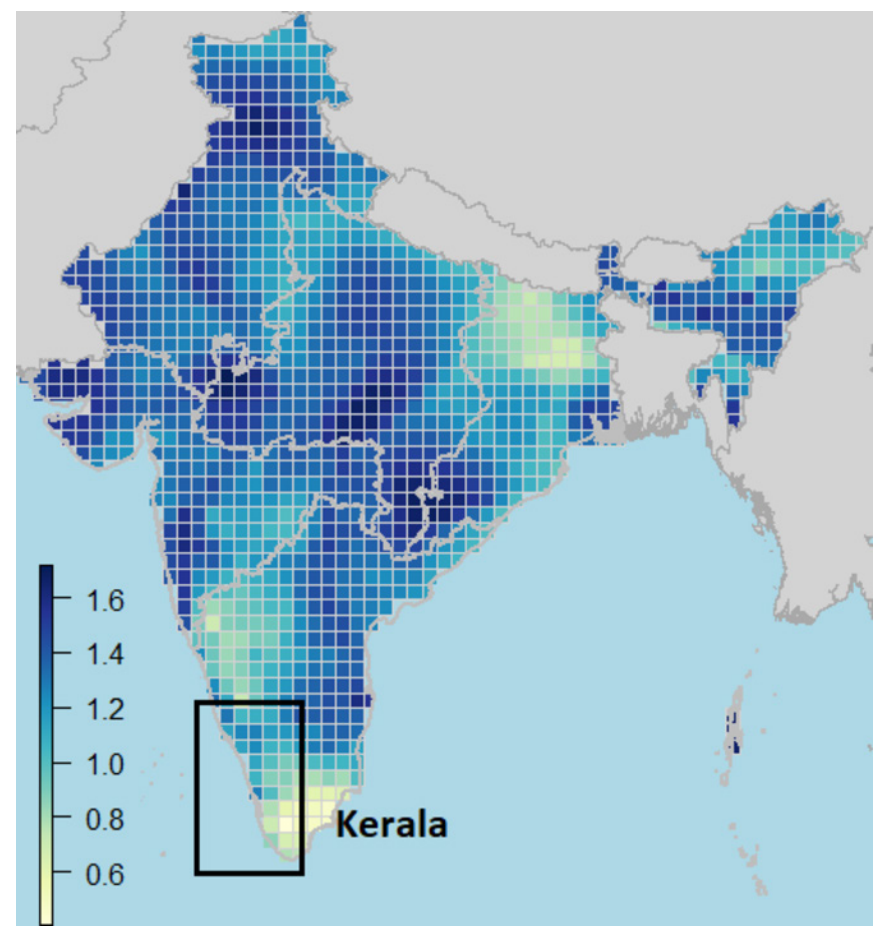

Figure 1 Maximum monsoon season Standardized Precipitation and Evapotranspiration Index by grid cell in India (mean 2010-2016). events. SPEI distribution over $2010-2016$ by grid cells in India is presented in figure 1. More detailed discussion on the data and methods is provided in the online supplementary appendix 1 .

Focusing on the south of India where Kerala is located, we investigate the relationship between exposure to floods (measured as SPEI $>1.5$ ) and the likelihood of being stunted and wasted for children aged under 5 . Defined as height-for-age z scores more than 2 SD below the WHO Child Growth Standards median, stunting indicates chronic childhood malnutrition which impairs growth and development in children. Wasting is defined as weight-for-height $\mathrm{z}$ scores more than $2 \mathrm{SD}$ below the WHO Child Growth Standards median and indicates acute weight loss over a short period of time. For the analysis of stunting, we consider climate during the child's life up until the time when the child was measured in the survey, whereas for the analysis of wasting, we consider exposure to floods during the latest 3 months before measurement. The effects of undernutrition are shown to be long-lasting and can influence health and socioeconomic outcomes in adulthood. ${ }^{15}$

Our data analysis shows that exposure to floods can indeed exacerbate malnutrition in Kerala. While there is no regional differences in the probability of stunting in normal time, we find that accumulative exposure to abnormally wet conditions over the child's lifetime up to aged 5 increased the odds of stunting by $18 \%$ for children living in the southern region, and $7 \%$ for children living in the Central and Eastern regions $(95 \%$ confidence) (figure 2). This finding suggests that Kerala is particularly vulnerable to flood-induced childhood stunting compared with other regions in India. We do not find evidence that recent exposure to abnormally wet conditions (during the latest 3 months prior to measurement) increased the overall likelihood of wasting in the south although this is the case for the north and central regions. Looking at exposure to extreme SPEI of population subgroups; however, we do find evidence that floods

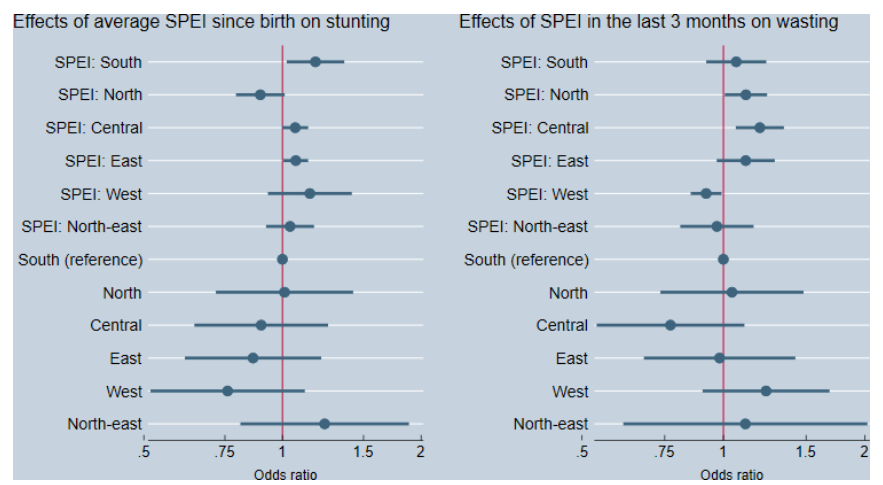

Figure 2 Effects of average Standardized Precipitation and Evapotranspiration Index (SPEI) since child's birth on the likelihood of stunting (right) and effects of SPEI in the last 3 months prior to measurement on likelihood of wasting (left) (with 95\% Cls) by region in India ( $n=196061)$. 

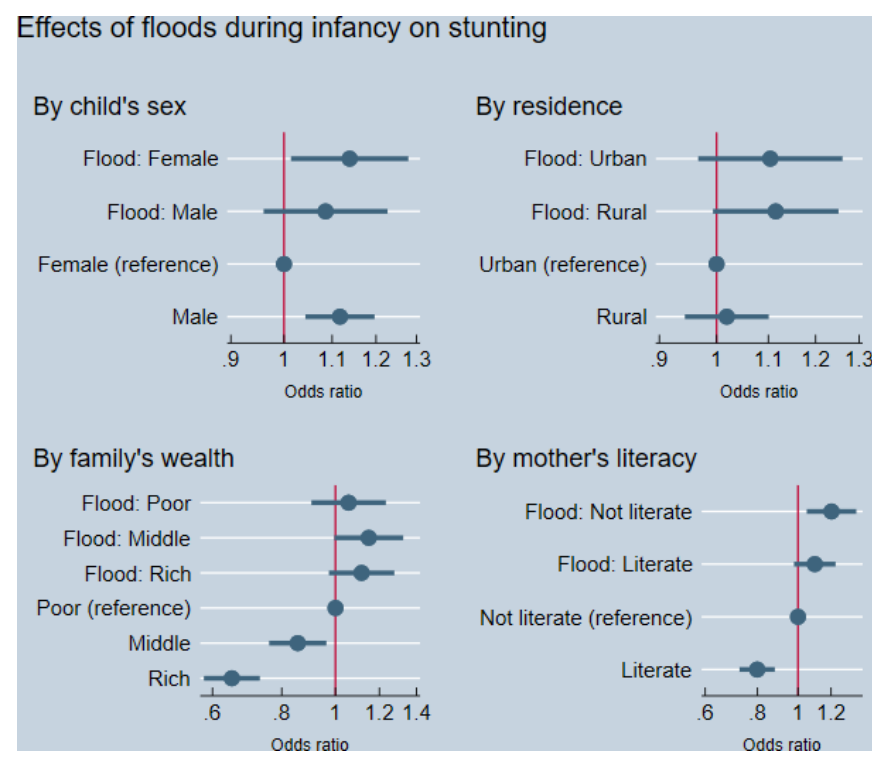

Figure 3 Effects of floods during infancy on likelihood of stunting (with 95\% Cls) by individual and household characteristics, southern region $(n=20$ 928).

do exacerbate childhood wasting in the south as well (see figure 4).

Since India's central government turned down international assistance for flood relief measures, there was a concern by Kerala state government that their pledge for rupees 20 billion (approximately US $\$ 285$ million) for immediate aid may not be met. ${ }^{16}$ Furthermore, in the postflood Kerala, given that much of the public funds will be directed to rebuild livelihoods, homes and infrastructure, interventions to reduce flood-induced undernutrition are unlikely to receive priority. Failing to address the increase of undernutrition prevalence however can seriously undermine India's strive for the Sustainable Development Goals. With limited public resources to tackle undernutrition, the government will need to identify the vulnerable segment of the populations that urgently need interventions.

Employing the demographic differential vulnerability approach considering the differential impacts of floods on population subgroups, ${ }^{17}$ we carried out some further analysis focusing on the southern region. Our analysis identifies that the most critical age for stunting from exposure to floods is when the child is in infancy (aged $<1)$. Experiencing floods during this period increased the odds of stunting by $12 \%$ (95\% confidence).

In figure 3, we further compare the likelihood of undernutrition by child's sex, rural-urban residency, household wealth and mother's literacy. While boys are generally more likely to be stunted or wasted than girls given their higher energy usage, our data show that when experiencing floods, girls are more vulnerable than boys to being stunted and being wasted. This is because when food is scarce, households may adopt gender-based discrimination in feeding practices. Poorer households generally have much higher likelihood of stunting and wasting but exposure to floods also increased the

\section{Effects of floods in the last 3 months on wasting}
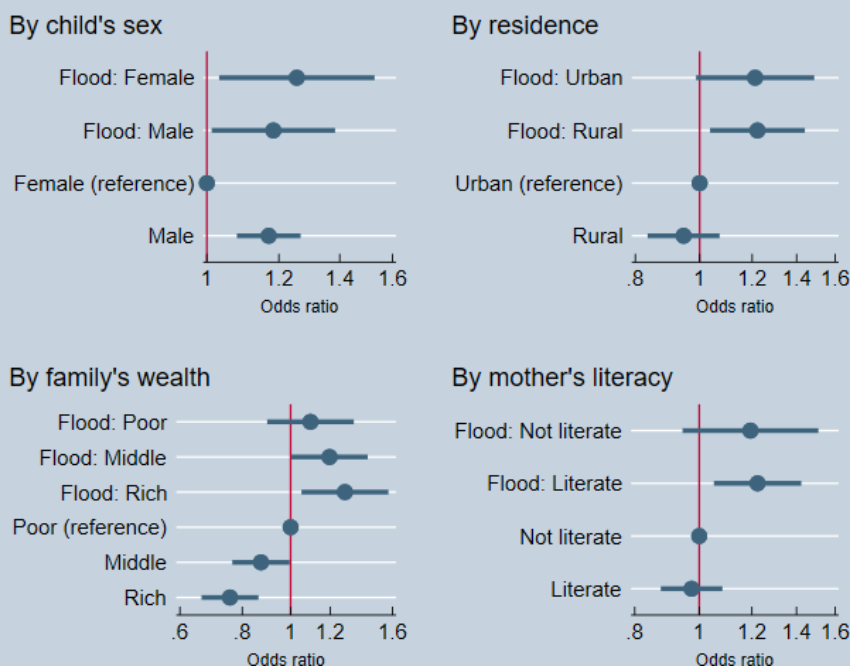

Figure 4 Effects of floods in the 3 months prior to measurement on likelihood of wasting (with $95 \% \mathrm{Cls}$ ) by individual and household characteristics, southern region $(n=21392)$.

likelihood of stunting and wasting for children living in a household in the middle and high wealth tertile. Likewise, children living with illiterate mothers are particularly vulnerable to stunting, and flood exposure further exacerbates this disadvantage. On the other hand, exposure to floods increases the likelihood of wasting for children of illiterate and literate mothers in a similar magnitude (figure 4). Wasting represents acute malnutrition, and it is plausible that the negative impact of floods on nutritional status is so strong that even literate mothers did not have enough time and resources to mitigate the risk of her child becoming wasted. Finally, we find that exposure to floods increases the likelihood of wasting for children living in the rural area.

\section{CONCLUSION}

Although it is too early to gauge the health impacts of the current Kerala floods, our results imply that childhood undernutrition, especially the chronic one is likely to be heightened in the floods aftermath. It is still not too late to implement actions to reverse the course of this negative health consequence of floods. Nutritional and water and sanitation interventions should be particularly directed to households with pregnant women and infants, poor and middle-wealth households and mothers who are not literate. It is also important to ensure that there is no gender differential in feeding practice. With evidence showing the increased frequency of floods in India due to climate change, ${ }^{18}$ we present the danger of short-term and long-term health consequences of floods on children and highlight how this can undermine sustainable development. 
Contributors RM designed the study, performed literature search and wrote the main text. $A D$ prepared and analysed the data, provided data interpretation and described the results.

Funding The International Institute for Applied Systems Analysis (IIASA) funded the publication of this article. IIASA encourages and actively supports its researchers to publish their research in journal articles or books that are made available for free to all users (gold open access)

Competing interests None declared.

Patient consent for publication Not required.

Provenance and peer review Not commissioned; externally peer reviewed.

Data sharing statement № additional data are available.

Open access This is an open access article distributed in accordance with the Creative Commons Attribution Non Commercial (CC BY-NC 4.0) license, which permits others to distribute, remix, adapt, build upon this work non-commercially, and license their derivative works on different terms, provided the original work is properly cited, appropriate credit is given, any changes made indicated, and the use is non-commercial. See: http://creativecommons.org/licenses/by-nc/4.0/.

\section{REFERENCES}

1. Döll P, Trautmann T, Gerten D, et al. Risks for the global freshwater system at $1.5^{\circ} \mathrm{C}$ and $2^{\circ} \mathrm{C}$ global warming. Environ Res Lett $2018 ; 13$.

2. India Meteorological Department. Performance of South West monsoon 2018 over Kerala, 2018. Available: https://www.imdtvm. gov.in/images/cumulative\%20rainfall\%20for\%20kerala\%20-\% 20sw\%20monsoon\%202018.pdf

3. Times. The Economic Times. 483 dead, flood loss more than Kerala's annual outlay: Vijayan. Econ, 2018. Available: https:// economictimes.indiatimes.com/news/politics-and-nation/483-deadflood-loss-more-than-keralas-annual-outlay-vijayan/articleshow/ 65606817.cms

4. IDMC. East Africa worst hit by internal displacement in first half of 2018. Geneva: Internal Displacement Monitoring Centre, 2018.
5. Ahern M, Kovats RS, Wilkinson P, et al. Global health impacts of floods: epidemiologic evidence. Epidemiol Rev 2005;27:36-46.

6. Alderman K, Turner LR, Tong S. Floods and human health: a systematic review. Environ Int 2012;47:37-47.

7. Zhong S, Yang L, Toloo S, et al. The long-term physical and psychological health impacts of flooding: a systematic mapping. Sci Total Environ 2018:626:165-94.

8. Mahanta R, Das D. Flood induced vulnerability to poverty: evidence from Brahmaputra Valley, Assam, India. Int J Disaster Risk Reduct 2017;24:451-61.

9. Mazumdar S, Mazumdar PG, Kanjilal B, et al. Multiple shocks, coping and welfare consequences: natural disasters and health shocks in the Indian Sundarbans. PLoS One 2014;9:e105427.

10. Mehar M, Mittal S, Prasad N. Farmers coping strategies for climate shock: is it differentiated by gender? J Rural Stud 2016;44:123-31.

11. UNICEF. Who, world bank. UNICEF/WHO/World bank joint child malnutrition estimates expanded database. New York: UNICEF, World Health Organization and World Bank, 2018.

12. Phalkey RK, Aranda-Jan C, Marx S, et al. Systematic review of current efforts to quantify the impacts of climate change on undernutrition. Proc Natl Acad Sci U S A 2015;112:E4522-9.

13. Stewart MK, Fauveau V, Chakraborty J, et al. Post-flood nutritional anthropometry of children in Matlab, Bangladesh. Ecol Food Nutr 1990;24:121-31.

14. Rodriguez-Llanes J, Ranjan-Dash S, Mukhopadhyay A, et al. FloodExposure is associated with higher prevalence of child undernutrition in rural eastern India. IJERPH 2016;13.

15. Adair LS, Fall CHD, Osmond C, et al. Associations of linear growth and relative weight gain during early life with adult health and human capital in countries of low and middle income: findings from five birth cohort studies. The Lancet 2013;382:525-34.

16. Withnall A. India to 'politely' reject foreign aid for Kerala flooding crisis. Independent, 2018. Available: https://www.independent.co. uk/news/world/asia/kerala-floods-inida-aid-reject-international-helpdead-rescue-rebuild-a8502406.html [Accessed 27 Dec 2018]

17. Muttarak R, Lutz W, Jiang L. What can demographers contribute to the study of vulnerability? Vienna Yearb Popul Res 2016;2015:1-13.

18. Alfieri $L$, Bisselink $B$, Dottori $F$, et al. Global projections of river flood risk in a warmer world. Earth's Future 2017;5:171-82. 